\title{
QUEEN'S
UNIVERSITY
BELFAST
}

\section{Review of William Chaigneau, The History of Jack Connor, ed. Ian Campbell Ross}

Regan, S. (2016). Review of William Chaigneau, The History of Jack Connor, ed. Ian Campbell Ross . Irish University Review, 46(2), 383-386. https://doi.org/10.3366/iur.2016.0235

\section{Published in:}

Irish University Review

\section{Document Version:}

Peer reviewed version

Queen's University Belfast - Research Portal:

Link to publication record in Queen's University Belfast Research Portal

Publisher rights

(c) 2016 Edinburgh University Press

\section{General rights}

Copyright for the publications made accessible via the Queen's University Belfast Research Portal is retained by the author(s) and / or other copyright owners and it is a condition of accessing these publications that users recognise and abide by the legal requirements associated with these rights.

Take down policy

The Research Portal is Queen's institutional repository that provides access to Queen's research output. Every effort has been made to ensure that content in the Research Portal does not infringe any person's rights, or applicable UK laws. If you discover content in the Research Portal that you believe breaches copyright or violates any law, please contact openaccess@qub.ac.uk. 
William Chaigneau, The History of Jack Connor, edited by Ian Campbell Ross. Dublin: Four Courts Press, 2013. EUR 55.00

The Four Courts Press edition of The History of Jack Connor constitutes the first modern text of the only novel by William Chaigneau, an eighteenth-century Irish author of Huguenot descent. Originally published in 1752, Chaigneau's narrative is a fascinating, if in some ways peculiar work. Combining comic, picaresque, and sentimental elements with less obviously novelistic matter, the text presents itself simultaneously as an Irish Tom Jones and as a compendium of proposals for social and economic improvement. These elements come together in the figure of Jack Connor himself. Jack's is a tale of rags to riches, albeit of a realistic rather than a fantastical bent. Born into beggary in Limerick and abandoned when young, the illegitimate Jack soon comes into the improving ambit of Lord Truegood at BountyHall in County Meath (an Irish spin on Fielding's Squire Allworthy and his Paradise Hall) before being educated at Portarlington. Following some early sexual dalliances and his exile from this paradise of personal and pedagogical cultivation, Jack follows a typical picaro's progress via various situations as an apprentice, servant, highwayman, and soldier, before marrying (twice) and returning to Ireland enriched and ready to make his own contribution to the narrative of national improvement. Through this circuitous route, the forsaken Irish bastard thus becomes an enlightened social benefactor.

Beginning and ending in Ireland with excursions to England, France, Spain and the Netherlands, the novel covers much terrain, both geographical and discursive. As Ian Campbell Ross observes in his informative and well-crafted introduction, Chaigneau's narrative is a rogue's tale with serious designs upon contemporary political discourse. Accordingly, the introduction places the work within a range of literary and historical contexts. The novel's publication in the early 1750s locates it within a rich and formative moment in the history of the novel genre. The five years preceding its publication, for instance, saw the appearance of Fielding's Tom Jones and Amelia, Richardson's Clarissa, Smollett's Roderick Random and Peregrine Pickle, and Smollett's English translation of Lesage's Gil Blas, along with less securely canonical works such as John Cleland's Memoirs of a Woman of Pleasure and Francis Coventry's Pompey the Little. As Ross foregrounds, this was a period of 
considerable discussion concerning the constituents and pretensions of the fledgling genre, which was carried on both in the works themselves and in reviews (in the recently established Monthly Review), periodical essays (including Johnson's Rambler) and stand-alone pieces such as An Essay on the New Species of Writing Founded by Mr. Fielding (1751), a work usually attributed to Francis Coventry. Chaigneau's contribution to this pivotal moment involved drawing together some of the strands of this multi-faceted discourse while offering innovations of his own. Even as it adopts Fielding's self-conscious narrator, Jack Connor contains a number of formal firsts, being the first novel to include mottoes to each chapter and the first to change its title during the course of the action: part-way through volume 1 chapter 13, as Jack heads to London, the running header morphs from 'Jack Connor' to 'Jack Connor, now Conyers', and the title-page to the second volume follows suit, thereby differing from that to the first volume. As Ross observes, this is part of the 'experimental' nature of 1750 s fiction, which has been increasingly noted by critics in recent years. At the same time, experimentalism is always relative: the novelties here are few in comparison with some of the other novels published during the same decade (culminating in the appearance of Tristram Shandy at the decade's end), and even these might have been elaborated further. As Steven Moore recently noted in The Novel: An Alternative History, 1600-1800 (Bloomsbury, 2013), for instance, Chaigneau missed a typographical trick by not having the surname in the running header change to 'Constant' when Jack once more alters his name, albeit temporarily, early in volume 2 .

Beyond these formal whim-whams, Jack Connor extended the sense of the genre's significance and educative potential via a series of practical proposals. The novel's suggestions for economic and instructional reform centre on Ireland. As Ross indicates, a key concern of Jack Connor is 'the state of Ireland and the dangers of absentee landlordism'. In the opening chapters, Ireland appears as a nation of rural deprivation, in which the fortunes of Jack's family are intertwined with the broader theme of absenteeism: early on, the wife of Sir Roger Thornton insists on their relocating to England following her discovery of Sir Roger's affair with Dolly Bright, Jack's Catholic mother. The novel's solution to the Irish problem at this time lies in the promotion of charity schools (and the extension of English Charter schools into Ireland) and various modest proposals for economic development. (Intriguingly, as 
Ross outlines, later editions of the novel were bound with a 1740s work titled Stultus versus Sapientem, 'a collection of short, ironic pamphlets on Irish politics, population, and industry'.) Related to this concern with advancing Irish education and industry is the novel's overt resistance to contemporary anti-Irish prejudices. Early on, Lord Truegood points out that, to the Irish, the accents of the English sound alien and peculiar. Over in England, Jack himself initially meets with some mockery for his brogue and for what are stereotypically viewed as his 'Bulls and Blunders', though in the main he manages successfully to mask his Irish origins, and only intermittently risks attracting suspicion by contesting expressions of anti-Irish feeling. Overall, the edition perhaps underplays the prejudice that remains on display in the novel's distinction between 'Irish and Irish': between Protestant landowners and the impoverished 'common Irish'. One of the aims of the reforming schemes outlined in the novel is, after all, to eliminate Catholicism in Ireland, not by physical force but by suasion and stealth; educating the Catholic natives, the novel assumes, will allow them to become enlightened into 'True Religion'. English investment and lordly habitation in Ireland are thus presented by Chaigneau as elements in a positive-sum game that will benefit the English financially and the Irish culturally and spiritually.

Indeed, if this is an Irish Tom Jones or Irish picaresque, it is also a Hanoverian novel and a Huguenot one. The social landscape of the novel is heavily populated with Huguenots: during his travels, Jack happens upon Huguenots as easily as, later in the decade, Thomas Amory’s John Buncle encounters learned ladies and acquires wives. In the novel's political schema, William of Orange is the 'PROTESTANT ARCHITECT', fountainhead of the Protestant Revolution; symptomatically, Jack's first wife dies from a miscarriage brought on by being told 'a most frightful Story of the Rebellion'. As with the native Irish, the novel is both moderate and patronising in its attitude to Jacobites, who simply need to be educated and gently persuaded out of their 'Zeal to mistaken Opinions' to see the (Protestant) light. More broadly, the novel's pro-Hanoverian agenda takes the form of extended comparisons between England and France. One of Chaigneau's polemical points is that the true threat to English Protestantism comes from Catholic France, rather than from Irish Catholics; more precisely, that it is only through the political machinations of the former that the latter pose any kind of threat to the Protestant Settlement. 
At times, the coverage of such political and national issues risks waylaying the novel as a work of creative invention. In Ross' view, 'it would be wrong to imagine that the seriousness of Chaigneau's novel is achieved at the expense of the narrative itself'. Yet the concern with personal and national improvement does occasionally unbalance the work. Two chapters that are taken up with outlining the Truegoods' virtuous life and rational management of their household, for instance, verge on what the narrator at this point explicitly disavows: allowing the story to become the 'Memoirs of Lord TRUEGOOD' rather than the 'History of JACK CONNOR'. At such moments, Jack himself is marginalised narratively as well as socially. Indeed, as Ross himself concedes, the characteristic narrative stuff of the novel at this time - the entertaining 'adventures' to be found in Tom Jones or Roderick Random - is consciously downgraded by Chaigneau, as when the narrator informs us that 'THE Occurrences on the Road are not worth mentioning', that the 'Adventures of this Voyage of ten Days' will not be described, or that 'no Accident happen'd on the Road'. For a work that has been viewed as a mid-century "ramble” novel, Jack Connor is surprisingly unwilling to relate such plot events, the comic mishaps and misadventures that occur during the hero's travels. In the stead of such narrative dynamism, Chaigneau often seems to prefer more static, conversational set-pieces. Elsewhere, his adoption of the conventional materials of popular fiction sometimes appears half-hearted, not least during the Connor family reconciliation scene as Jack's mother confirms his identity by revealing 'a large Mole on his Leg, (which he had never observ'd)': a bathetic moment which reads like a cut-price variation on Joseph Andrews' strawberry birthmark, in Fielding's novel of 1742.

Chaigneau may well have felt that such low adventures and conventional plot elements detracted from his broader seriousness of purpose. Following the publication of Jack Connor, he would also respond to his critics regarding another facet of the 'low': his hero's sexual liaisons. Ross' detailed annotations enable the reader to retrace the extensive efforts that Chaigneau made, in the second edition of 1753 , to defend Jack's conduct and to tone down what the Monthly Review had termed the novel's 'levities'. (He also added a request for donations to the Charter Schools surely another first in the history of the genre.) Happily, Ross' exemplary edition returns us to the livelier, less defensive version of the work as it first appeared in 1752. The edition is the sixth volume to be published in Four Courts' Early Irish 
Fiction series (with a seventh, Daniel Roberts' edition of Charles Johnston's Arsaces, also now published). As with the other volumes in the series, the dust-jacket is nicely illustrated with the novel's original title-page, glossily surrounded by a single bold colour (in this instance, an appropriately Williamite orange). In all respects, indeed, this is a stylish scholarly edition, which clearly satisfies the series' aim of revealing the ‘diversity and breadth’ of Irish prose fiction during the long eighteenth century, and which should cement Jack Connor's place within critical discussions of fiction published by Irish writers before Edgeworth.

SHAUN REGAN 